\title{
CLINICAL-ANAMNESTIC PECULIARITIES OF THE COURSE OF NEONATAL SEPSIS IN NEWBORNS
}

\author{
Olena V. VLASOVA ${ }^{1 凶}$, Larysa V. KOLIUBAKINA ${ }^{1}$, Natalia M. KRECU ${ }^{1}$ \\ ${ }^{1}$ Department of Pediatrics and Children's Infectious Diseases, Higher State Educational Institution of \\ Ukraine „Bukovinian State Medical University“, Chernivtsi, Ukraine \\ Received 8 June 2018, Accepted 19 Aug 2018 \\ https://doi.org/10.31688/ABMU.2018.53.3.15
}

\begin{abstract}
Background. Scientific and technological progress, environmental problems of society, prolonged use of broad-spectrum antibiotics, as well as the peculiarities of the immune response of the newborn's body, which are accumulated on the disorders of the postnatal adaptation, contribute to the selection of microorganisms, with the formation of antibiotic-resistant strains. Material and methods. A retrospective analysis of medical records of newborns with neonatal sepsis, born in Chernivtsi maternity hospitals, Ukraine, during 2017 has been carried out.
\end{abstract}

Results. Among infants with neonatal sepsis, premature newborns from mothers with probable risk factors for the development of generalized bacterial infection prevailed. The disease was characterized by the symptoms of multiple organ failure, with a predominant defeat of the respiratory system, hemodynamics disorders, changes in the neurological status, and a decrease in food tolerance. According to the results of bacteriological cultures of blood, the predominance of microorganisms association was established, the leading place among them belonged to Klebsiella pneumoniae.

Conclusions. Prematurely born infants (84\% in our study) prevailed among newborns with neonatal sepsis,

\section{RÉsumÉ}

Particularités cliniques et anamnestiques de l'évolution de la septicémie néonatale chez les nouveau-nés

Introduction. Les progrès scientifiques et technologiques, les problèmes écologiques de la société, l'utilisation prolongée d'antibiotiques à large spectre, ainsi que les particularités de la réponse immunitaire des nouveau-nés s'ajoutant à la détérioration de l'adaptation postnatale, contribuent à la sélection des micro-organismes avec la formation de souches résistantes aux antibiotiques.

Matériel et méthodes. Une analyse rétrospective des cartes médicales des nouveau-nés avec de la septicémie néonatale, nés dans les maternités de la ville de Tchernivtsi en 2017, a été menée.

Résultats. Il a été démontré que parmi les nourrissons avec de la septicémie néonatale prédominaient les bébés prématurés provenant principalement de mères présentant des facteurs de risque probables de développement d'une infection bactérienne généralisée. La maladie était caractérisée par des signes de défaillance de plusieurs organes avec une défaite prédominante du système respiratoire, une violation de l'hémodynamique, un changement de l'état neurologique et 
from mothers with potential risk factors for systemic bacterial infection development. Fatal cases were observed among premature infants, especially with an extremely low body weight, which accounted for $60 \%$ of deaths, and with antibiotic resistant strains of Klebsiella pneumoniae cultures.

Keywords: early and late neonatal sepsis, newborns, epidemiological study, antibiotic resistance.

\section{INTRODUCTION}

Neonatal sepsis remains one of the most important medical and social issues in neonatology. The introduction of modern perinatal technologies during deliveries of high-risk, the nursing of extremely premature infants, and the improvement of existing diagnostic and therapeutic methods contributed to the reduced infant mortality rate on the one hand, but also led to an increase in the morbidity and mortality of newborns in cases of generalized infectious and inflammatory diseases of various etiology and localization, on the other hand. Scientific and technological progress, environmental problems of society, prolonged use of broad-spectrum antibiotics, as well as the peculiarities of the immune response of the newborn's body, which reflect on the disorders of the postnatal adaptation, contribute to the selection of microorganisms with the formation of antibiotic-resistant strains ${ }^{1.4}$.

The etiology of neonatal sepsis is represented by a wide range of pathogens, the peculiarity of which is the prevalence of a combination of microorganisms, in which one or two pathogens play a leading role, while the rest - create a background. In the diseases' evolution and treatment, the role of the leading agent may change. The risk of early sepsis, which occurs in the first 72 hours of life, is associated primarily with bacterial invasion of the mother's organism. These can be both Gram-positive and Gram-negative microorganisms. Streptococcus group B, Escherichia coli, Streptococcus viridans, Enterococci, Staphylococcus aureus are predominantly the pathogens that induce early manifestations of the disease. The development of late sepsis manifestations (after une diminution de la tolérance alimentaire. Selon les résultats des ensemencements de sang par culture bactériologique, la prédominance de l'association de microorganismes a été établie, parmi lesquels la principale place était occupée par Klebsiella pneumoniae.

Conclusions. Parmi les bébés avec de la septicémie néonatale, les prématurés prédominaient, dont $84 \%$ d'entre eux de mères présentant des facteurs de risque potentiels de développement d'infection bactérienne systémique. Des cas mortels ont été observés chez les nourrissons prématurés, en particulier chez ceux avec un poids extrêmement réduit, qui représentait $60 \%$ des décès, et chez ceux aux souches de Klebsiella pneumoniae résistantes aux antibiotiques.

Mots-clés: septicémie néonatale précoce et tardive, nouveau-nés, étude épidémiologique, résistance aux antibiotiques.

72 hours of life) is most often associated with infections called "providing medical care" to newborns, dealing with premature birth of children, long-term inpatient treatment, use of invasive treatment and examination methods, connected with nosocomial infections, with high resistance to antibacterial drugs. Thus, Klebsiella pneumoniae, Escherichia coli, coagulase negative staphylococci, Staphylococcus aureus, Pseudomonas aeruginosa, Enterococci, Acinetobacter spp., Acinetobacter baumannii, Candida albicans are most often the etiological causes of late infections. According to the literature sources ${ }^{5-9,11-12}$, Klebsiella pneumoniae and Enterobacteriaceae are the causative agents in $3-20 \%$ of cases of late neonatal sepsis, having the ability to persist in the external environment and to form stable foci of nosocomial infection. The formation of hospital strains is associated with the property of these agents to produce $\beta$-lactamase of expanded spectrum, carbapenemase, cross-resistance due to the presence of R-plasmids (DNA of resistance gene carriers) and the ability to form biofilms on the surface of the vascular, urinary catheters and endotracheal tubes ${ }^{10,13}$.

The risk of neonatal sepsis development is inversely proportional to gestational age, newborn body weight and is directly proportional to the degree of severity of an infant's disorder. The analysis of recent reference data showed that early sepsis in premature infants is characterized by severe course and unfavorable consequences. So, if the weight of newborns is less than one and a half kilogram, the probability of sepsis development is 10 times higher, and if the weight is less than 1 kilogram, it is 100 times higher than that of mature newborn infants $^{14-16}$. 
The OBJective OF THE STUDY was to study the clinical and anamnestic features of the evolution of neonatal sepsis in the newborns from the city of Chernivtsi, Ukraine.

\section{Material AND MEthods}

A retrospective analysis of morbidity and mortality caused by neonatal sepsis has been carried out among 25 newborns in the municipal maternity hospitals from Chernivtsi, Ukraine, during 2017, according to infants' personal development records. Parents of sick children have agreed to use the materials of disease history in the study.

\section{Results}

The proportion of boys was $68 \%$. According to the parity of deliveries, $48 \%$ of infants were born from the first pregnancy, the rest - from the second or subsequent deliveries. Almost half of the infants $(56 \%)$ were born by cesarean section, because of the development of fetal distress and/or breech position. In $12 \%$ of cases infants were born from multiple pregnancy, among which an antenatal death of the fetus in one case at the $8^{\text {th }}$ week of pregnancy was registered.

The following pathologies were observed in the history: the threat of abortion was noted in $24 \%$ of cases, the retardation of the intrauterine development of the fetus - in $8 \%$ of cases, and isolated indications for the presence of TORCH-infection in mother and preeclampsia with anemia - in $4 \%$ of the cases. Chorioamnionitis was diagnosed in almost every third woman (32\%), exacerbation of chronic pyelonephritis in $20 \%$, vaginitis in $44 \%$, and abscess pneumonia in one mother; these were the most common perinatal infectious factors. The prolonged anhydrous interval, which is one of the risk factors for the development of neonatal sepsis, was noted in every fourth woman (25\%) and averaged over 63.5 hours. 32\% of mothers received antibiotic therapy with cephalosporins of the third generation because of positive bacterial culturing from the vagina prior to the delivery. According to the gestational age, the proportion of mature infants with neonatal sepsis constituted $16 \%$, the rest $-84 \%$ were premature births, among which the proportion of small premature infants was $32 \%$. Based on the weight curve data, $20 \%$ of infants were born with an extremely low weight ( $<1000 \mathrm{~g}), 12 \%$ of newborns - from 1000 to $1500 \mathrm{~g}$, and 52\% of infants with a low body weight at birth $(1500-2500 \mathrm{~g})$. The average weight at birth was $1845 \mathrm{~g}$.

Every fifth child was born with severe asphyxia, requiring primary resuscitation maneuvers. Moderate asphyxia was diagnosed in $72 \%$ of cases. There were only two babies born with a high Apgar score (7/8). A severe altered general status after the delivery was noted in $32 \%$ of infants, an average degree of severity - in $56 \%$ of newborns, and three were born with a satisfactory condition.

Antibiotic therapy was administered to infants in $84 \%$ of cases, because of the high risk of intrauterine infection. Ampicillin was administered in combination with amikacine in age-adjusted doses, as an initial empirical antibiotic therapy, in $76 \%$ of cases, and amoxicillinum-clavulanate with amikacine - in $8 \%$ of cases. The deterioration of the general condition of infants, with phenomena of multiple organ failure such as respiratory failure, changes in neurological status, decreased tolerance to food, and impairment of hemodynamics in the third day were noted in almost every second child (52\%). In 48\% of cases, the deterioration of the general condition occurred after the third day. The development and increase of the phenomena of multiple organ failure required additional examination of the newborn and intensification of antibiotic therapy.

Analyzing the species spectrum of bacterial culturing, carried out in pregnant women before delivery, it was noted that microorganisms Enterococcus faecalis, Escherichia coli, Candida albicans, Staphylococcus aureus were encountered with almost the same frequency. According to the regulatory orders, bacteriological studies of available bio-environments in newborns during the time of staying in the maternity home were performed. According to gathered data, only $48 \%$ of babies had positive results of bacterial culturing in the first day of life at laboratory examinations. In the process of further bacteriological research, associations of pathogens Escherichia coli and Klebsiella pneumoniae; Enterococcus faecalis and Klebsiella pneumoniae; Klebsiella pneumoniae and Staphylococcus aureus; Enterococcus faecalis and Staphylococcus epidermidis represented the highest proportion, accounting for more than $60 \%$ of cases.

\section{Discussion}

For neonatal sepsis in newborns, the Enterobacteria family has the highest epidemiological significance, among which Klebsiella pneumoniae occupies a special place, accounting for almost $75-85 \%$ of cases of neonatal sepsis ${ }^{17-21}$. The Enterobacteria family is normally part of the microbiocenosis of intestine and urogenital tract, and can be isolated from the nasopharynx, upper respiratory tract, and skin. Both the premature infants, who represent the risk group, and the phenotypic peculiarities of the pathogen are of great importance, namely their ability to produce 
$\beta$-lactamase of a wide spectrum, which leads to fatal consequences. So, according to our data, Klebsiella pneumoniae antibiotic resistant strain cultures were found in five infants (20\%), three of whom died. The relative risk of death in the presence of an antibiotic resistant strain of Klebsiella pneumoniae is RR 6.0 (95 CI 1.34-26.8), OR 13.5 (95 CI 1.34-135.9).

$80 \%$ of neonates, in addition to multiple organ failure, presented a hemorrhagic syndrome, with thrombocytopenia; this is reported also in the literature $^{22-25}$. The elevated level of C-reactive protein, as a marker of the infectious-inflammatory process of the newborn, was noted in only three children (12\%) with early neonatal sepsis.

Children with neonatal sepsis were transferred to the Regional Children's Clinical Hospital of Chernivtsi for further treatment. Despite timely diagnosis and treatment, lethality due to neonatal sepsis was $20 \%$. All the children who died were prematurely born. The share of children with extremely low body weight among them was $60 \%$. The relative risk of loss from neonatal sepsis in infants with an extremely low weight is RR 4.8 (95 CI 1.09-21.10), OR 10.5 (95 CI 1.02-107.17).

THE LIMITS OF THE STUDY were the small number of patients included and the retrospective nature of the study.

\section{Conclusions}

The prematurely born infants (84\% in our study) prevailed among newborns with neonatal sepsis, from mothers with potential risk factors for systemic bacterial infection development.

The evolution of neonatal sepsis led to symptoms of multiple organ failure, with respiratory failure, hemodynamics impairment, changes in neurological status and decreased tolerance to food.

Regarding the epidemiology, associations of microorganisms have been encountered, among which Klebsiella pneumoniae occupied the leading place.

Fatal cases were observed among premature infants, especially with an extremely low body weight, which accounted for $60 \%$ of cases, and with antibiotic resistant strains of Klebsiella pneumoniae cultures.

\section{Compliance with Ethics Requirements:}

„The authors declare no conflict of interest regarding this article"

"The authors declare that all the procedures and experiments of this study respect the ethical standards in the Helsinki Declaration of 1975, as revised in 2008(5), as well as the national law. Informed consent was obtained from all the patients included in the study"

"No funding for this study"

\section{References}

1. El-Din EMRS, El-Sokkary MMA, Bassiouny MR, et al. Epidemiology of neonatal sepsis and implicated pathogens: a Study from Egypt. BioMed Research International 2015;2015:1-11.

2. Bizzarro MJ, Sabo B, Noonan M, et al. Quality improvement initiative to reduce central line associated bloodstream infections in a neonatal intensive care unit. Infection Control $\mathbb{E}$ Hospital Epidemiology 2010;31:241-248

3. Simonsen KA, Anderson-Berry AL, Delair SF, et al. Early-onset neonatal sepsis. Clinical Microbiology Reviews 2014;27(1):21-47.

4. Chan GJ, Lee ACC, Baqui AH, et al. Risk of early-onset neonatal infection with maternal infection or colonization: a global systematic review and meta-analysis. PLoS Med 2013;10(8):1001-502.

5. Hartman ME, Linde-Zwirble WT, Angus DC, Watson RS. Trends in the epidemiology of pediatric severe sepsis. Pediatric Critical Care Medicine 2013;14(7):686-693.

6. Lin FY, Weisman LE, Azimi P, et al. Assessment of intrapartum antibiotic prophylaxis for the prevention of early-onset group B streptococcal disease. Pediatric Infection Disease Journal 2011; 30(9):759-763.

7. Srinivasan L, Kirpalani H, Cotten CM. Elucidating the role of genomics in neonatal sepsis. Seminars in Perinatol 2015; 39 (8):611-6

8. Groer MW, Gregory KE, Louis-Jacques A, Thibeau S, Walker WA. The very low birth weight infant microbiome and childhood health. Birth Defects Res C Embryo Today 2015;105(4):252-64.

9. van den Hoogen A, Gerards LJ, Verboon-Maciolek MA, Fleer A, Krediet TG. Long-term trends in the epidemiology of neonatal sepsis and antibiotic susceptibility of causative agents. Neonatology 2010; 97(1):22-8

10. Stoll BJ. Infections of the neonatal infant. In: Nelson Textbook of Pediatrics (Ed. By Kliegman RH, Behrman RE, Jenson HB, Starton BF), 18th Ed., Saunders., 2007: 794-811.

11. Bizzarro MJ, Shabanova V, Baltimore RS, et al. Neonatal sepsis 2004-2013: the rise and fall of coagulase-negative staphylococci. The Journal of Pediatrics 2015;166(5):1193-99.

12. Moles L, Gomez M, Heilig H, et al. Bacterial diversity in meconium of preterm neonates and evolution of their fecal microbiota during the first month of life. PLoS ONE 2013;8(6):669-86.

13. Stoll BJ, Hansen NI, Sánchez PJ, et al. Early onset neonatal sepsis: the burden of group B streptococcal and E. coli disease continues. Pediatrics 2011;127:817-826.

14. Anderson-Berry AL, Bellig LL, Ohning BL, et al. Neonatal sepsis. Available at: http://emedicine.medscape.com/ article/978352-overview. (accessed on May 9, 2018)

15. Hornik CP, Fort P, Clark RH, et al. Early and late onset sepsis in very-low-birth-weight infants from a large group of neonatal intensive care units. Early Human Development 2012;88(2):69-74.

16. Selimovic A, Skokic F, Bazardzanovic M, Selimovic Z. The predictive score for early-onset neonatal sepsis. The Turkish Journal of Pediatrics 2010;52(2):139-44. 
17. Janda JM, Abbott SL. The Genera Klebsiella and Raoultella. The Enterobacteria. 2nd ed, Washington, USA. ASM Press, 2006:115-129.

18. Broberg CA, Palacios M, Miller VL. Klebsiella: a long way to go towards understanding this enigmatic jet-setter. F1000 Prime Reports 2014;6:64.

19. Podschun R, Ullmann U. Klebsiella spp. as nosocomial pathogens: epidemiology, taxonomy, typing methods, and pathogenicity factors. Clinical Microbiology Reviews 1998;4(11):589-603.

20. Asensio A, Oliver A, González-Diego P, et al. Outbreak of a multiresistant Klebsiella pneumoniae strain in an intensive care unit: antibiotic use as risk factor for colonization and infection. Clinical Infectious Diseases 2000;30:55.
21. Antimicrobial resistance: global report on surveillance // World Health Organization 2014. http://www. who.int/ drugresistance/en (accessed on May 12, 2018)

22. Tsaregorodtsev AD, Khaertynov KhS, Anokhin VA, et al. Neonatal sepsis caused by Klebsiella. Russian Bulletin of Perinatology and Pediatrics 2016;4:49-54.

23. Ree IMC, Fustolo-Gunnink SF, Bekker V, Fijnvandraat KJ, Steggerda SJ, Lopriore E. Thrombocytopenia in neonatal sepsis: Incidence, severity and risk factors. Simeoni U, ed. PLoS ONE 2017;12(10):e0185581.

24. Arif SH, Ahmad I, Ali SM, Khan HM. Thrombocytopenia and bacterial sepsis in neonates. Indian Journal of Hematology $\mathcal{E}$ Blood Transfusion 2012;28(3):147-151.

25. Ghanghoriya PK, Gedam DS. Neonatal septicemia and thrombocytopenia. International Journal of Medical Research and Review 2015;3(2):139-140. 